\title{
Article \\ COVID-19 Effects and Resilience of Vegetable Farmers in North-Western Nigeria
}

\author{
Rosaine N. Yegbemey ${ }^{1,2, * \mathbb{D}}$, Christelle M. Komlan Ahihou ${ }^{1}$, Ifeoluwa Olorunnipa ${ }^{3}$, Marwan Benali ${ }^{1}$, \\ Victor Afari-Sefa ${ }^{1}$ (D) and Pepijn Schreinemachers ${ }^{4, *}$ (D) \\ 1 World Vegetable Center, West and Central Africa (WCA)—Coastal and Humid Regions, IITA-Benin Campus, \\ Cotonou 08 BP 0932, Benin; christelle.komlan@worldveg.org (C.M.K.A.); marwan.benali@gmail.com (M.B.); \\ victor.afari-sefa@worldveg.org (V.A.-S.) \\ 2 Faculté d'Agronomie, Université de Parakou, Parakou BP 123, Benin \\ 3 Sahel Consulting Agriculture and Nutrition Limited, Plot 817 A, Cadastral Zone B04, Off Ebitu Ukiwe Street, \\ Jabi District, Abuja 900211, Nigeria; ifeoluwa@sahelcp.com \\ 4 World Vegetable Center, East and Southeast Asia, P.O. Box 1010, Bangkok 10903, Thailand \\ * Correspondence: rosaine.yegbemey@worldveg.org (R.N.Y.); pepijn.schreinemachers@worldveg.org (P.S.)
}

Citation: Yegbemey, R.N.; Komlan Ahihou, C.M.; Olorunnipa, I.; Benali, M.; Afari-Sefa, V.; Schreinemachers, P. COVID-19 Effects and Resilience of Vegetable Farmers in North-Western Nigeria. Agronomy 2021, 11, 1808. https://doi.org/10.3390/ agronomy11091808

Academic Editor: Gabrijel Ondrasek

Received: 19 August 2021

Accepted: 2 September 2021

Published: 9 September 2021

Publisher's Note: MDPI stays neutral with regard to jurisdictional claims in published maps and institutional affiliations.

Copyright: (c) 2021 by the authors. Licensee MDPI, Basel, Switzerland. This article is an open access article distributed under the terms and conditions of the Creative Commons Attribution (CC BY) license (https:// creativecommons.org/licenses/by/ $4.0 /)$.

\begin{abstract}
The COVID-19 pandemic has particularly affected the supply of perishable foods such as vegetables, which could adversely affect food and nutrition security. Here, we study the mechanisms by which COVID-19 has affected vegetable production and the coping strategies adopted by smallholder farmers. We use cross-sectional data collected through individual interviews on a random sample of 521 vegetable producers in north-western Nigeria. The perceptions of respondents, measured on a 5-point Likert scale (from 1-not affected, to 5-severely affected), shows that COVID-19 had an average effect of $3.07( \pm 1.23)$ on vegetable production. Farmers also reported challenges in accessing farm inputs and storing or selling fresh vegetable produced. In response, farmers reduced market-oriented vegetable production, produced more vegetables for own consumption, added value through own home processing and storage, explored new markets, and accepted lower farmgate selling prices. A multivariate probit regression shows that socio-economic factors such as age, household size, marital status, challenges in accessing inputs, and perceptions of the effects of COVID-19 influenced farmers' decisions to adopt particular coping strategies. To sustain vegetable supplies, policy makers should consider investing more in market-oriented strategies such as vegetable processing and storage, which individual farmers may not be able to afford due to high costs, lack of information and required knowledge on good agronomic practices, postharvest handling, storage and market. Public extension services can contribute to help farmers to adapt better.
\end{abstract}

Keywords: food security; coping strategies; horticulture; market; multivariate probit; social security

\section{Introduction}

The COVID-19 pandemic decreased food production and reduced access of consumers to food as a result of constraints to the distribution of farm inputs, travel restrictions and reduced purchasing power [1-6]. A reduction in vegetable production and availability is likely to adversely affect food and nutrition security in many developing countries where vegetable consumption is already far below the recommendation of the World Health Organization (WHO) [7]. A better understanding of how smallholder vegetable producers have been coping with the COVID-19 pandemic will help shed light on the specific actions needed to support them and sustain vegetable supply chains for food and nutrition security throughout the pandemic. Most of the fast-growing literature on the impact of COVID-19 on food supply chains focuses on food demand and supply shocks [8], with less attention to the resilience of smallholder farmers. Beyond the ongoing pandemic, an analysis of how vegetable farmers respond to a crisis such as the COVID-19 pandemic is relevant to 
better prepare for future crises that will affect agricultural production and food systems and ensure the resilience of vegetable production and its market supply.

We conducted a study in north-western Nigeria to analyse the effects of the COVID-19 pandemic on vegetable farmers and the coping strategies they have applied. We also aim to understand how the choice of coping strategies is driven by underlying socio-economic factors. Our study contributes to the existing literature in three major ways. First, we focus on vegetable production as vegetables are broadly acknowledged to have a high potential to improve food and particularly nutrition security $[9,10]$, but there is a gap between actual and optimal vegetable consumption. Second, we contribute to the literature on the impact of COVID-19 on agricultural production systems by reporting on farm-level strategies developed to respond to the crisis. Following [11], we define a coping strategy as shortterm, location-specific actions or adjustments against the effects of COVID-19. We separate between production- and market-oriented coping strategies. Third, by analysing the socioeconomic drivers of the coping strategies, we highlight key areas of intervention that could be considered by policy makers to support micro-level responses to and recovery from the COVID-19 pandemic among smallholder farmers in general and vegetable producers in particular. The results can also inform coping strategies to deal with future crises.

The COVID-19 pandemic has exacerbated the increasing prevalence of all forms of malnutrition (stunting, wasting, overweight, and obesity) [12]. Within Africa, major cities such as Lagos (Nigeria), Accra (Ghana), and Johannesburg (South Africa) recorded the highest COVID-19 infections in 2020 [13]. In response, governments enacted measures to reduce the spread of the virus such as border closures, lockdowns, travel restrictions, curfews, market closures, and school closures. The COVID-19 crisis has affected everyday social, economic, and political activities and the lives of billions of people globally [14], including smallholder farmers. The agricultural sector in Africa is considered relatively resilient but still at risk of serious disruption as restrictions affect input and output markets [15]. In labour-intensive sub-sectors such as fruits, vegetables, meat, and dairy production, the availability of agricultural workers is increasingly becoming a problem [16]. Limited availability of farm inputs is expected to reduce input use among farmers, which may lead to reduced production and rising food prices, which could have devastating effects on food and nutrition security.

Vegetables are broadly acknowledged as an essential part of healthy diets and a key food item to address malnutrition (including micronutrient deficiencies and overweight/obesity) as well as a source of income to rural and urban dwellers [17]. In the context of COVID-19, vegetable consumption is more than ever advocated for proper nutrition and good health to strengthen human immunity to the coronavirus [18]. Despite this importance, vegetable production is at risk from the ravaging effects of the COVID-19 pandemic.

Some studies have assessed the effect of COVID-19 on food supplies and food security in general [19-22]. Fewer studies have assessed the impact of COVID-19 on vegetable value chains $[5,18,21,23]$, and even fewer are from sub-Saharan Africa [2,24], Following these studies, vegetable value chains are at risk since they rely heavily on labour while labour supply is threatened by the COVID-19 pandemic [21]. The pandemic also reduces trade and consumption as well as farm production (e.g., reduced farmer prices as fewer traders are traveling to rural areas because of the restrictions, increased farm losses due to the lack of buyers, shortage of farm inputs and increased input prices as a result of land border closings, scared labour, etc.) [22]. To the best of our knowledge, there is no micro-level evidence from the supply side in terms of the smallholder farmers' responses to COVID-19 and the socio-economic drivers underlying the observed responses.

Against this background, we argue that supporting smallholder farmers' coping strategies could help sustain vegetable production and the food supply chains with positive spillovers in terms of food and nutrition security as well as resilience to COVID-19. We conducted a study to identify the coping strategies developed by vegetable farmers and most importantly to analyse the key socio-economic drivers underlying the identified 
coping strategies. The remainder of the paper is organised as follows: Section 2 presents the research methods and analytical approaches, Section 3 discusses the results while Section 4 concludes the paper, drawing on the aforementioned results.

\section{Materials and Methods}

\subsection{Sampling and Data Collection}

We conducted our study in selected states of north-western Nigeria. Nigeria's countrywide lockdown started in March 2020. About 87\% of Nigeria's rural households are involved in crop farming [25]. Vegetables are among the most important crops commonly grown in both rural and peri-urban areas and are very important to the diets of the whole population [26].

Our study is part of a larger study aimed at measuring the adoption and impact of vegetable technologies in north-western Nigeria. We focused on Kano and Kaduna states, which account for $30 \%$ of the country's population [27]. These are important vegetable producing states and among the three major tomato producing states in the country known as the "tomato triangle". The population of Kano and Kaduna relies on agriculture as a major source of livelihood and agriculture employs around half of the labour force, although it contributes to less than a quarter of the state's gross domestic product [28].

The sample unit is the household, which is represented by the person managing vegetable production, who is in most cases a male household head or someone delegated by the household head. Our sample involved 521 households selected through a multistage proportional sampling technique. The first stage was the selection of the states, using stratified sampling in terms of population size, security status in terms of possible militant attacks, and importance of the state in the Nigeria economy. The second stage involved the selection of the 10 local government areas (LGAs), shown in Figure 1, based on the population size. The third and last stage was the selection of 29 to 80 vegetable producing households from each LGA. The selection of households in the third stage involved suggestions on households producing vegetables by the community heads in the various communities and a random selection of a sample of these households by enumerators (Table 1).

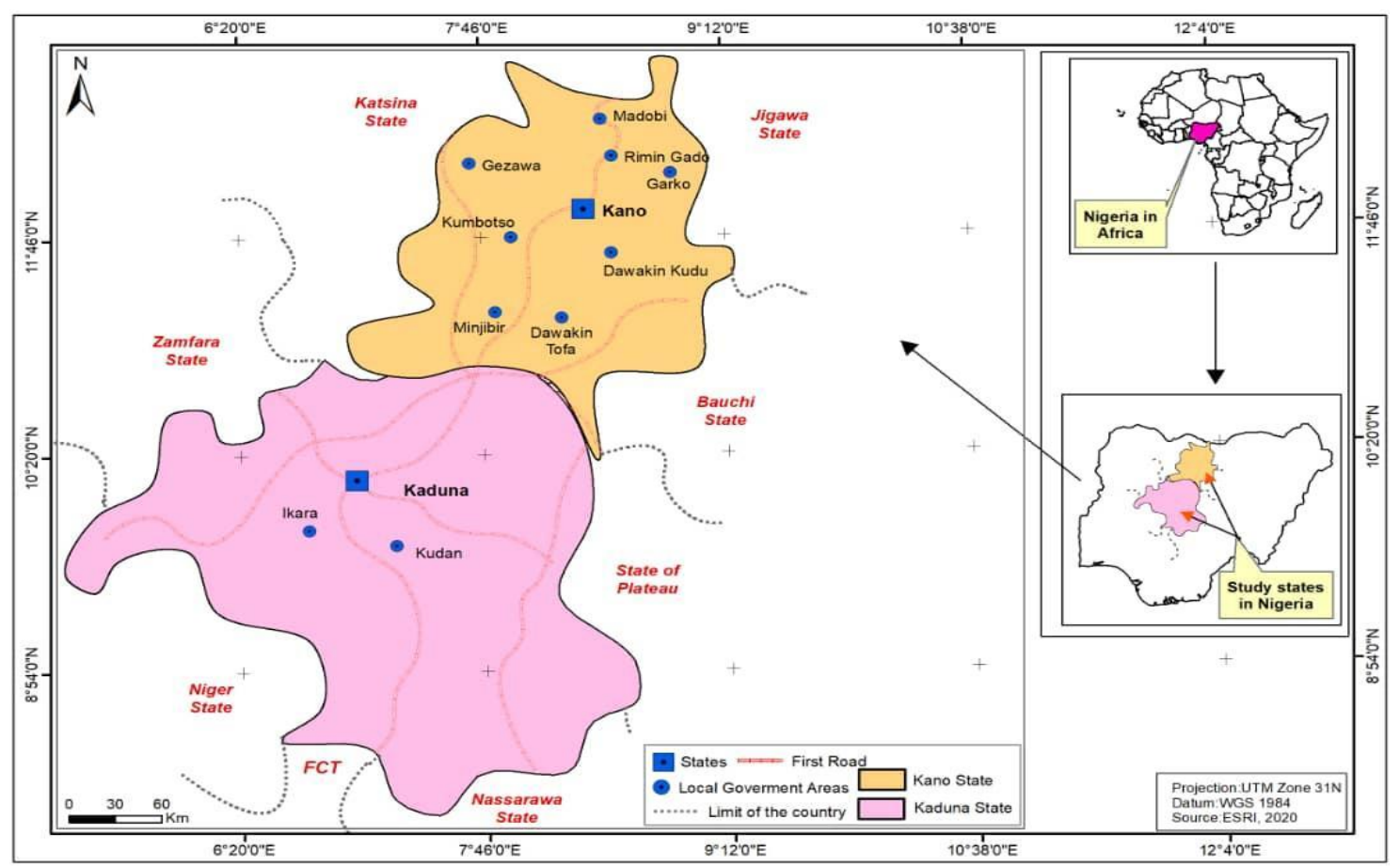

Figure 1. Map of the study area in Nigeria. 
Table 1. Sample structure.

\begin{tabular}{ccc}
\hline State & LGA & Sample Size \\
\hline \multirow{2}{*}{ Kudan } & Kudan & 59 \\
& Ikara & 50 \\
\hline & Dawakin Kudu & 80 \\
& Dawakin Tofa & 72 \\
& Minjibir & 29 \\
& Garko & 29 \\
& Kumbotso & 50 \\
& Rimin Gado & 50 \\
& Madobi & 51 \\
& Gezawa & 51 \\
\hline & Total & 521 \\
\hline
\end{tabular}

Data were collected using a structured questionnaire survey implemented using computer-assisted personal interviews (CAPI). We collected data on vegetable farmers' socio-economic characteristics (e.g., age, level of education, household size, household assets, contact with extension services, access to credit etc.), the perception of the effects of COVID-19 and its related measures, the challenges in accessing input and output markets, and the coping strategies developed in response to the effects of the COVID-19 pandemic. Data on perception of the effects of COVID-19 and its related measures and the challenges in accessing input and output markets were collected using a five-point Likert scale ( $1=$ no effect or no challenge at all, $2=$ minor effect, $3=$ moderate effect, $4=$ major effect, $5=$ severe effect or severe challenge). Data were collected by a team of local enumerators in September and October 2020, in-between two countrywide lockdowns in Nigeria. A similar period was used by other studies [20] that analysed the impact of COVID-19 on food systems and rural livelihoods in Nigeria.

\subsection{Data Analysis}

We used descriptive statistics such as means and standard deviations to describe the sample's socio-economic characteristics, perceptions of the effect of the COVID-19 pandemic, challenges in accessing inputs or markets, and COVID-19 coping strategies. We also used t-tests to check whether the self-reported challenges in accessing input or output markets were related to the COVID-19 crisis. Our main specification relies on a random utility model [29]. We consider that farmers can develop a broad range of coping strategies to the COVID-19 pandemic. Yet, the choice of any specific strategy likely depends on households' expected utility from it as compared to alternative strategies. The expected utility itself will be shaped by socio-economic, institutional or environmental characteristics of a decision-maker. Therefore, we can model the farmers' choice of a specific strategy as:

$$
A_{i}=\beta_{0}+\beta_{k} Z_{i k}+u_{i}
$$

where $A$ represents a dichotomous variable indicating the use (or absence thereof) of a given coping strategy, $\beta_{0}$ is the constant term, $\beta_{k}$ are the parameters to be estimated, $Z_{k}$ is a set of k socio-economic characteristics of the farm households, $i$ is the $i$ th household, and $u_{i}$ is a random error term.

We further assume that the decision to use a given coping strategy is related to the decision on other strategies. We therefore fitted a system of equations:

$$
A_{y i}=\beta_{0 y}+\beta_{y k} Z_{i k}+u_{y i} \text { with } y=1,2, \ldots n
$$

where $y$ represents each of the $n$ dichotomous coping strategy under consideration. We use a multivariate probit (MVP) model which estimates $k$-equation probit models, through the method of simulated maximum likelihood (SML) [30]. This specification was preferred 
over the univariate probit or logit because of its simultaneous estimation feature that accounts for possible correlations between the error terms of the single-equations in the model. These correlations can come from the fact that a similar set of unobservable factors and farmers' characteristics can influence the choice of each coping strategy or the choice of some coping strategies may be conditional on the choice of other strategies.

Following [31], we assume that the choice of a coping strategy is influenced by many factors, including knowledge, skills, attitudes, social, physical, material and societal resources. We considered a total of 13 variables in the regression model based on the following assumptions:

- $\quad$ Age: Age is a typical proxy for experience, wisdom, etc. We therefore expect that older people will be better able to cope with the COVID-19 pandemic.

- Level of education: Education is often linked to better knowledge to take informed decisions that ensure efficiency, higher income, etc. We hypothesise that more educated farmers will be more likely to adopt coping strategies.

- Household size: Larger households have more labour available and might be more flexible in terms of labour reallocation if hired labour were to become scarce. Due to the availability of labour, they can also be more flexible in terms of adopting strategies that might be more labour intensive. We assume that larger household will be more likely to adopt coping strategies in response to the COVID-19 pandemic.

- Marital status: Married farmers often have dependent household members and need considerable income flows from sales to meet non-food expenses. We anticipate that married farmers will be more likely to adopt coping strategies in response to the COVID-19 pandemic.

- Household assets: Ownership of assets can be seen as a proxy for wealth. Assets can be used to smoothen consumption or to pay for an investment to shield the household from a crisis. We hypothesise that assets are positively associated with the adoption of coping strategies.

- $\quad$ Access to credit: Like household assets, access to credit can help to sustain livelihoods or make adjustments to avoid losses. We assume that farmers who have access to credit will be more likely to adopt coping strategies.

- Vegetable production within the last twelve months: We assume that farmers who produce vegetables often will likely adopt coping strategies as a means to sustain their livelihoods. This variable can be seen as a proxy for farmers who are active in vegetable production with the assumption that these farmers will more likely be in a better position to adopt observed coping measures.

- Government extension services: Access to extension services can help farmers to change and build their resilience and capacity to deal with shocks [32] by exposing them to innovations, information, etc. Government extension services often provide farmers with general technical support. We expect that farmers with access to government extension services are better able to respond to the COVID-19 pandemic by adopting coping strategies.

- Private extension services: Like government extension services, private extension services from local or international non-governmental organisations provide support to farmers and often target specific areas or aspects of production. We anticipate that farmers with access to private extension services will be better able to adopt coping strategies.

- Scale of perception of the effects of COVID-19: We used a 5-point Likert scale from 1 (not affected at all) to 5 (severely affected) to measure the perception of the effects of COVID-19. We anticipate that the use of a coping strategy is by default a response of the perception of effects of the COVID-19 pandemic or its related effects. Hence, we assume that stronger perceptions about the effects of COVID-19 will be associated with the adoption coping strategies.

- Scale of challenges in accessing farm inputs: We also used a 5-point Likert scale from 1 (not affected at all) to 5 (severely affected) to measure the challenges in accessing 
farm inputs. As the COVID-19 pandemic is likely to slow down the distribution of farm inputs, we assume that farmers who already face challenges in accessing inputs might be less likely to cope with the effects of COVID-19 pandemic.

- Scale of challenges in vegetable storage and commercialisation: A 5-point Likert scale from 1 (not affected at all) to 5 (severely affected) was used to measure the challenge scale in vegetable storage and commercialisation. We assume that farmers who already face challenges in storing or marketing their vegetables will have more difficulties in coping with the effects of the COVID-19 pandemic as vegetables are highly perishable goods.

- LGA dummies: LGA's specific characteristics such as size, existence of basic infrastructure etc. could affect the behaviour of farmers. We controlled for differences between LGAs by using LGA dummies.

\section{Results and Discussion}

\subsection{Socio-Economic Characteristics of Respondents}

Table 2 presents the socio-economic profiles of households. On average, respondents were about 44 years old. All respondents were men and most of them were married with an average household size of about six persons. Mean literacy levels were low, and access to credit and contact with both government and private extension services were limited. About half of the respondents produced vegetables during the 12-month period before the survey. The profiles are similar across LGAs.

\subsection{Respondents' Perceptions of the Effects of COVID-19}

Table 3 shows the respondents' perception of the effects of different shocks, including the COVID-19 measures by using a Likert scale and Table 4 presents the respondents' perceptions on the effects of the COVID-19 measures.

Table 3 shows that the COVID-19 pandemic was by far the most important shock that households have experienced over the last five years. Regarding the effects of the COVID-19 pandemic, we included both the direct effects of COVID-19 measures (e.g., general lockdowns, curfews, market closures, social distancing, travel restrictions and quarantine) and the indirect effects on employment, loss of income or revenues, food shortages, cost of food, cost of medicines shortage in input supply. Table 4 shows that, on average, the COVID-19 pandemic had a moderate effect (score of $3.07 \pm 1.23$ ) on respondents. The main negative effects were associated with the general lockdown, curfew, input market closures and travel restrictions. Regarding indirect effects, key issues were the high cost of medications for addressing health issues and shortage in input supplies for farm operations. These results confirm those of Lapatinas [33] who observed that lockdowns had a significant negative effect on retail and recreation, grocery and pharmacy, parks, transit stations, and workplaces. These figures suggest that farmers will face more difficulties in producing and this could affect general food supplies. It is also important to note that farmers in Gezawa and Rimin Gado were more affected (higher perception score) than their counterparts in Madobi and Kumbutso.

These perceptions are consistent with findings from previous reports in Nigeria that indicated that the COVID-19 crisis and its associated effects (e.g., inter-state movement restriction, disruption to the rainy season farming and the logistics challenges associated with domestic food distribution) led to a tendency for more speculative buying and increases in food prices while farmers experienced a decline in their disposable income [34]. Vegetables were also reported along with other food items such as fish, fruit, potatoes, yams and tubers, bread, cereals, oils and fats to have driven the increase in food prices during the COVID-19 crisis [34]. Rising food prices reflect a shortage of supplies resulting from reduced production, lower food imports, and increasing demand [19]. 
Table 2. Descriptive statistics of the respondents' socio-economic characteristics.

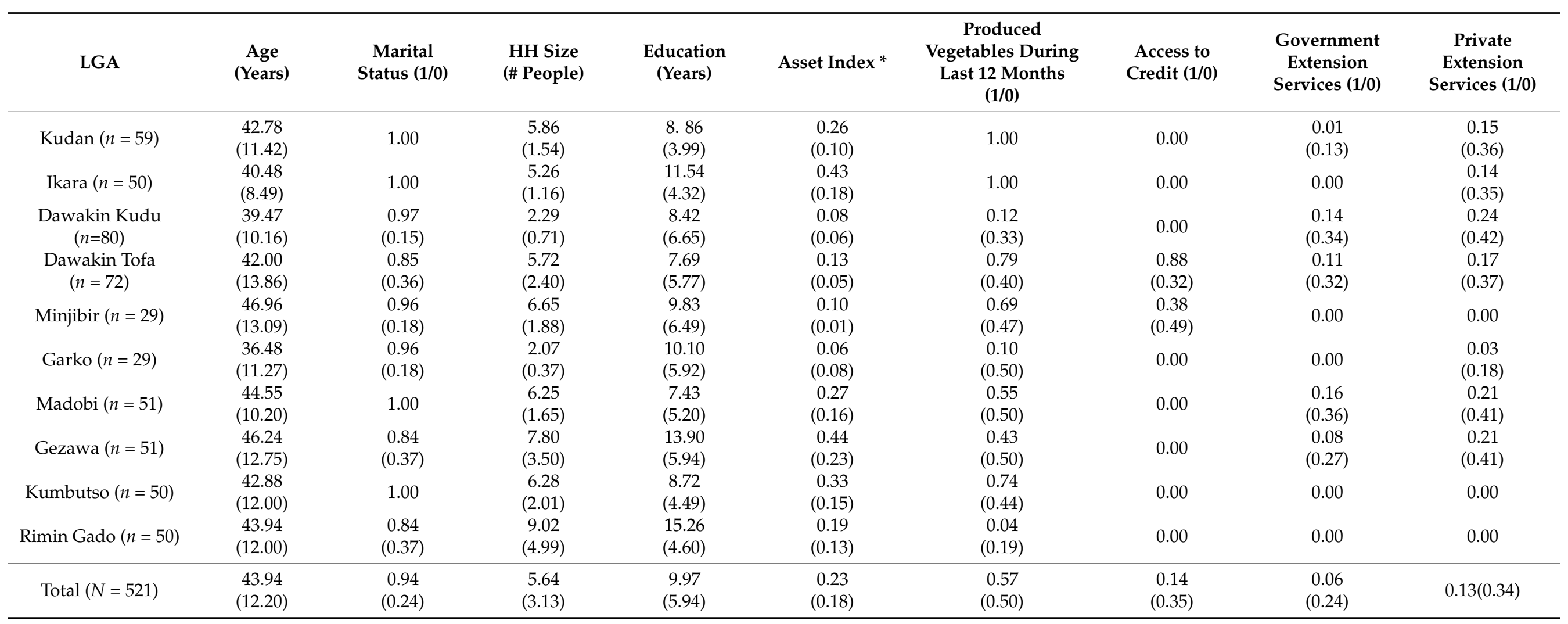

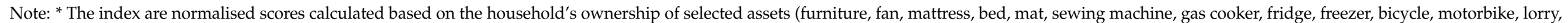
car, generator, hi-fi (sound system), iron, tv set, computer, DVD player and mobile phone) using principal component analysis. Values in parentheses are standard deviations. 
Table 3. Respondents' perceptions on the effects of shocks experienced over the last 5 years.

\begin{tabular}{ccccc}
\hline \multirow{2}{*}{ LGA } & \multicolumn{2}{c}{$\begin{array}{c}\text { Extent to Which Households Were Affected by [ . . ] Over the Last } 5 \text { Years on a Scale From 1 } \\
\text { (Not Affected at All) to 5 (Severely Affected) }\end{array}$} \\
\cline { 2 - 5 } & Natural Disasters A & Theft, Illness, Death B & Production Shocks ${ }^{\text {C }}$ & COVID-19 D \\
\hline Kudan $(n=59)$ & $1.00(0.04)$ & $1.02(0.08)$ & $1.04(0.12)$ & $2.62(0.39)$ \\
Ikara $(n=50)$ & $1.00(0)$ & $1.01(0.07)$ & $1.01(0.06)$ & $2.20(0.40)$ \\
Dawakin Kudu $(n=80)$ & $1.29(0.05)$ & $1.01(0.09)$ & $1.08(0.22)$ & $3.21(0.57)$ \\
Dawakin Tofa $(n=72)$ & $1.00(0)$ & $1.28(0.39)$ & $1.19(0.28)$ & $3.73(0.41)$ \\
Minjibir $(n=29)$ & $1.00(0)$ & $1.04(0.16)$ & $1.27(0.31)$ & $4.00(0.02)$ \\
Garko $(n=29)$ & $1.00(0)$ & $1.00(0)$ & $1.07(0.21)$ & $3.59(0.64)$ \\
Madobi $(n=51)$ & $1.00(0)$ & $1.02(0.13)$ & $1.12(0.19)$ & $1.21(0.19)$ \\
Gezawa $(n=51)$ & $1.26(0.41)$ & $1.28(0.60)$ & $1.37(0.28)$ & $4.43(0.39)$ \\
Kumbutso $(n=50)$ & $1.00(0)$ & $1.01(0.07)$ & $1.02(0.09)$ & $1.21(0.08)$ \\
Rimin Gado $(n=50)$ & $1.45(0.54)$ & $1.72(0.58)$ & $1.14(0.39)$ & $4.80(0.26)$ \\
Total $(N=521)$ & $1.11(0.33)$ & $1.15(0.37)$ & $3.07(1.23)$
\end{tabular}

Note: ${ }^{A}$ Includes major fire outbreak, flood/cyclone and drought. ${ }^{B}$ Includes major theft of household assets, major illness in the family, natural death in the family and divorce/separation. ${ }^{C}$ Includes major theft of agricultural assets including livestock or crop output, major crop disease, major animal disease, loss of land. ${ }^{\mathrm{D}}$ Includes both direct and indirect effects of the COVID-19 pandemic as described in Table 4. Values in parentheses are standard deviations.

Table 4. Respondents' perceptions on the effects of the COVID-19 measures.

\begin{tabular}{|c|c|c|c|c|c|c|}
\hline \multirow{2}{*}{ LGA } & \multicolumn{6}{|c|}{ Effect of the COVID-19 Measures [ ... ] on a Scale From 1 (Not Affected at All) to 5 (Severely Affected) } \\
\hline & $\begin{array}{c}\text { General } \\
\text { Lockdown }\end{array}$ & Curfew & $\begin{array}{c}\text { Input Market } \\
\text { Closure }\end{array}$ & $\begin{array}{c}\text { Social } \\
\text { Distancing }\end{array}$ & $\begin{array}{l}\text { Movement } \\
\text { Restriction }\end{array}$ & Quarantine \\
\hline Kudan $(n=59)$ & $3.71(0.72)$ & $1.95(1.07)$ & $3.74(0.54)$ & $1.20(0.52)$ & $3.10(0.80)$ & $1.34(0.88)$ \\
\hline Ikara $(n=50)$ & $3.98(0.14)$ & $1.62(1.09)$ & $2.80(0.95)$ & $1.16(0.42)$ & $2.32(0.87)$ & $1.10(0.42)$ \\
\hline $\begin{array}{c}\text { Dawakin Kudu } \\
\quad(n=80)\end{array}$ & $3.56(5.97)$ & $3.35(0.92)$ & $3.15(1.07)$ & $3.19(1.06)$ & $3.18(0.86)$ & $2.63(1.28)$ \\
\hline $\begin{array}{c}\text { Dawakin Tofa } \\
(n=72)\end{array}$ & $3.89(0.36)$ & $3.92(0.40)$ & $3.92(0.37)$ & $3.87(0.44)$ & $3.94(0.41)$ & $3.87(0.53)$ \\
\hline Minjibir $(n=29)$ & $4.00(0)$ & $4.03(0.19)$ & $4.00(0)$ & $4.00(0)$ & $4.00(0)$ & $4.00(0)$ \\
\hline Garko $(n=29)$ & $3.52(0.87)$ & $3.62(0.90)$ & $3.51(0.87)$ & $3.59(0.95)$ & $3.65(0.86)$ & $3.48(0.99)$ \\
\hline Madobi $(n=51)$ & $1.90(0.46)$ & $1.80(0.60)$ & $1.39(0.66)$ & $1.10(0.30)$ & $1.14(0.40)$ & $1.00(0)$ \\
\hline Gezawa $(n=51)$ & $4.90(0.30)$ & $4.76(0.47)$ & $4.59(0.57)$ & $4.51(0.70)$ & $4.55(0.64)$ & $3.14(1.48)$ \\
\hline $\begin{array}{l}\text { Kumbutso } \\
(n=50)\end{array}$ & $1.98(0.14)$ & $1.98(0.25)$ & $1.38(0.53)$ & $1.08(0.27)$ & $1.06(0.24)$ & $1.00(0)$ \\
\hline $\begin{array}{c}\text { Rimin Gado } \\
(n=50)\end{array}$ & $4.92(0.27)$ & $4.90(0.30)$ & $4.82(0.44)$ & $4.88(0.33)$ & $4.88(0.33)$ & $4.58(0.93)$ \\
\hline \multirow[t]{2}{*}{ Total $(N=521)$} & $3.63(1.09)$ & $3.16(1.38)$ & $3.32(1.30)$ & $2.83(1.57)$ & $3.16(1.37)$ & $2.55(1.55)$ \\
\hline & Employment & $\begin{array}{c}\text { Loss of } \\
\text { Income/Revenues }\end{array}$ & $\begin{array}{c}\text { Food } \\
\text { Shortages }\end{array}$ & Cost of Food & $\begin{array}{c}\text { Cost of } \\
\text { Medicines }\end{array}$ & $\begin{array}{l}\text { Shortage in } \\
\text { Input Supply }\end{array}$ \\
\hline Kudan $(n=59)$ & $1.81(0.80)$ & $2.47(0.86)$ & $2.49(1.07)$ & $3.52(0.73)$ & $2.90(0.86)$ & $3.24(0.75)$ \\
\hline Ikara $(n=50)$ & $2.06(0.71)$ & $2.38(0.83)$ & $1.90(0.91)$ & $2.50(0.73)$ & $2.52(1.09)$ & $2.12(0.94)$ \\
\hline $\begin{array}{c}\text { Dawakin Kudu } \\
\quad(n=80)\end{array}$ & 3.09 (1.19) & $2.91(1.24)$ & $3.30(0.10)$ & $3.44(0.98)$ & $3.32(0.94)$ & $3.40(1.14)$ \\
\hline $\begin{array}{l}\text { Dawakin Tofa } \\
\quad(n=72)\end{array}$ & 3.03 (1.37) & $3.49(0.99)$ & $3.72(0.59)$ & $3.71(0.54)$ & $3.72(0.51)$ & $3.71(0.49)$ \\
\hline Minjibir $(n=29)$ & $3.96(0.18)$ & $4.00(0)$ & $4.00(0)$ & $4.00(0)$ & $4.00(0)$ & $4.00(0)$ \\
\hline Garko $(n=29)$ & $3.79(0.82)$ & $3.48(1.09)$ & $3.62(0.98)$ & $3.65(0.97)$ & $3.52(0.91)$ & $3.62(0.90)$ \\
\hline Madobi $(n=51)$ & $1.04(0.28)$ & $1.04(0.19)$ & $1.04(0.28)$ & $1.06(0.31)$ & $1.04(0.20)$ & $1.00(0)$ \\
\hline Gezawa $(n=51)$ & $4.76(0.55)$ & $4.49(0.78)$ & $4.49(0.73)$ & $4.72(0.53)$ & $3.86(1.09)$ & $4.37(0.69)$ \\
\hline $\begin{array}{l}\text { Kumbutso } \\
(n=50)\end{array}$ & $1.00(0)$ & $0.98(0.14)$ & $1.00(0)$ & $1.00(0)$ & $1.02(0.14)$ & $1.02(0.14)$ \\
\hline $\begin{array}{c}\text { Rimin Gado } \\
(n=50)\end{array}$ & $4.82(0.39)$ & $4.90(0.30)$ & $4.66(0.63)$ & $4.88(0.33)$ & $4.64(0.66)$ & $4.82(0.48)$ \\
\hline Total $(N=521)$ & $2.85(1.54)$ & $2.96(1.47)$ & $2.99(1.45)$ & $3.24(1.40)$ & $3.04(1.36)$ & $3.11(1.41)$ \\
\hline
\end{tabular}




\subsection{Scale of Challenges in Vegetable Production, Storage and Sale}

Tables 5 and 6 show heat maps of the scales of challenges faced by the respondents in producing, storing and selling vegetables. Respondents faced small to moderate challenges in accessing inputs during the COVID-19 pandemic, mostly of pesticides, fertilisers, and seeds. There were some differences across LGAs though. On average, the crisis created difficulties in accessing all kinds of inputs as shown by the highlighted cells. This is consistent with the above-reported perception of the shortage in input supplies. The lockdown measures and movement restrictions during the COVID-19 pandemic contributed to a shortage of labour for agricultural production by limiting access to farmland by farmers and farm workers $[34,35]$. The effect of the crisis on the access to inputs is stronger in the LGAs of Dawakin Kudu and Minjibir, and to some extent in the LGAs of Ikara, Dawakin, Gezawa, and Rimin Gado.

Table 5. Heat map of the scale of challenges experienced by farmers in accessing various inputs in vegetables production as a result of the COVID-19 pandemic.

\begin{tabular}{|c|c|c|c|c|c|c|c|}
\hline LGA & $\begin{array}{l}\text { Access to } \\
\text { Seeds }\end{array}$ & $\begin{array}{l}\text { Access to } \\
\text { Fertilisers }\end{array}$ & $\begin{array}{l}\text { Access to } \\
\text { Pesticides }\end{array}$ & $\begin{array}{c}\text { Hired Casual } \\
\text { Labour }\end{array}$ & $\begin{array}{l}\text { Agricultural } \\
\text { Equipment }\end{array}$ & $\begin{array}{l}\text { Access to } \\
\text { Credit }\end{array}$ & Mean Score \\
\hline Kudan $(n=59)$ & $1.13(0.51)$ & $1.20(0.55)$ & $1.19(0.57)$ & 1.00 & 1.00 & $0.18(0.75)$ & $0.95(0.28)$ \\
\hline Ikara $(n=50)$ & $1.00(0)$ & $1.28(0.78)$ & 1.00 & 1.00 & $1.06(0)$ & $0.10(0.50)$ & $0.91(0.21)$ \\
\hline $\begin{array}{l}\text { Dawakin Kudu } \\
\quad(n=80)\end{array}$ & $1.16(0.51)$ & $1.35(0.08)$ & $1.44(0.91)$ & $1.44(0.92)$ & $1.50(0.00)$ & $0.30(0.85)$ & $1.20(0.67)$ \\
\hline $\begin{array}{l}\text { Dawakin Tofa } \\
\quad(n=72)\end{array}$ & $1.80(1.33)$ & 2.89 (1.39) & $2.75(1.40)$ & $1.05(0.84)$ & $0.92(0.57)$ & $0.30(0.23)$ & $1.57(0.75)$ \\
\hline $\begin{array}{l}\text { Minjibir } \\
(n=29)\end{array}$ & $1.52(1.40)$ & $2.55(1.78)$ & $2.69(1.85)$ & $0.96(1.05)$ & $0.69(0.47)$ & 0.00 & $1.40(0.97)$ \\
\hline Garko $(n=29)$ & $1.34(0.81)$ & $1.34(0.77)$ & $1.52(1.02)$ & 1.55 (1.12) & 1.59 (1.05) & $0.31(0.85)$ & $1.27(0.79)$ \\
\hline $\begin{array}{l}\text { Madobi } \\
(n=51)\end{array}$ & 1.00 & 1.00 & 1.00 & $1.05(0.31)$ & 1.00 & 0.00 & $0.84(0.05)$ \\
\hline $\begin{array}{l}\text { Gezawa } \\
(n=51)\end{array}$ & $2.78(0.81)$ & $3.20(1.00)$ & $3.25(0.18)$ & $2.88(1.12)$ & $2.82(0.97)$ & $2.29(0.92)$ & $2.87(0.60)$ \\
\hline $\begin{array}{l}\text { Kumbutso } \\
(n=50)\end{array}$ & 1.00 & 1.00 & 1.00 & 1.00 & 1.00 & 1.00 & $0.83(0)$ \\
\hline $\begin{array}{c}\text { Rimin Gado } \\
(n=50)\end{array}$ & $2.62(0.72)$ & $2.56(0.88)$ & $3.36(0.77)$ & $2.64(0.72)$ & $2.86(0.70)$ & $2.36(0.69)$ & $2.73(0.35)$ \\
\hline Total $(N=521)$ & $1.53(0.98)$ & $1.83(1.23)$ & $1.90(1.31)$ & $1.45(0.99)$ & $1.44(0.97)$ & $0.55(1.07)$ & $1.45(0.89)$ \\
\hline
\end{tabular}

Note: Values are challenge scales in assessing [ . . ] based on a scale from 1 (no challenge encountered) to 5 (severe challenge, was impossible to access). Colours reflect $p$-values based on $t$-tests between the scale of each challenge and the dichotomous (yes $/$ no) perception that the challenges were worsened by the COVID-19 pandemic. Values in green, blue and red indicate $p>0.10,0.05$ and 0.01 , respectively. Values in parentheses are standard deviations.

On average, vegetable producers faced small to moderate COVID-19 related challenges to vegetable storage and selling. The effect on storage and selling is more perceptible in the LGAs of Gezawa and Rimin Gado, and less in Minjibir, Dawakin Kudu, Dawakin, and Garko. The score is slightly larger (average challenge score about $1.77 \pm 1.09$ ) than in production (average challenge score about $1.45 \pm 0.88$ ). Most importantly, there are more heated cells in Table 6 than in Table 5. This suggests that the COVID-19 pandemic created more challenges post-harvest than pre-harvest. This can be explained by the high perishability of vegetables as well as the potentially reduced market demand for vegetable crops resulting from income losses experienced by consumers. Hence, farmers were able to sustain vegetable production, but faced more difficulties in selling it.

Overall, we note that the scale of challenges appears somewhat lower than those reported by other studies. This can be explained by the timing of data collection between two subsequent countrywide lockdowns. This is also consistent with other reports [36] showing that the proportion of Nigerian households reporting challenges in accessing markets declined from about $40 \%$ at the end of May to between $25-30 \%$ in June and July. 
Table 6. Heat map of the scale of challenges experienced by farmers in storage and selling as a result of the COVID-19 pandemic.

\begin{tabular}{|c|c|c|c|c|c|c|c|}
\hline LGA & $\begin{array}{l}\text { Lack of } \\
\text { Storage }\end{array}$ & $\begin{array}{c}\text { Lack of } \\
\text { Transportation } \\
\text { Means }\end{array}$ & $\begin{array}{c}\text { Closure/ } \\
\text { Restriction of } \\
\text { Markets }\end{array}$ & $\begin{array}{c}\text { Lack of } \\
\text { Buyers/Markets }\end{array}$ & $\begin{array}{c}\text { Low Selling } \\
\text { Prices }\end{array}$ & $\begin{array}{l}\text { Access to } \\
\text { Credit }\end{array}$ & Mean Score \\
\hline Kudan $(n=59)$ & $1.07(0.41)$ & $1.13(0.60)$ & $1.13(0.60)$ & $1.22(0.67)$ & $1.22(0.64)$ & $1.05(0.28)$ & $1.14(0.36)$ \\
\hline Ikara $(n=50)$ & $1.08(0.39)$ & $1.20(0.61)$ & $1.26(0.72)$ & $1.28(0.78)$ & $1.36(0.85)$ & 1.00 & $1.20(0.48)$ \\
\hline $\begin{array}{c}\text { Dawakin Kudu } \\
\quad(n=80)\end{array}$ & $1.47(0.97)$ & $1.42(0.92)$ & $1.47(0.99)$ & $1.50(1.03)$ & $1.35(0.76)$ & $1.26(0.69)$ & $1.41(0.75)$ \\
\hline $\begin{array}{l}\text { Dawakin Tofa } \\
\quad(n=72)\end{array}$ & 1.74 (1.11) & $2.14(1.21)$ & $2.24(1.28)$ & $2.30(1.14)$ & $2.36(0.31)$ & $2.12(0.24)$ & $2.15(1.13)$ \\
\hline $\begin{array}{l}\text { Minjibir } \\
(n=29)\end{array}$ & $1.83(1.46)$ & $2.10(1.52)$ & $2.10(1.52)$ & $2.24(1.57)$ & $2.21(1.54)$ & $2.10(1.50)$ & $2.10(1.46)$ \\
\hline Garko $(n=29)$ & $1.17(0.66)$ & $1.21(0.62)$ & $1.31(0.81)$ & $1.24(0.73)$ & $1.14(0.51)$ & $1.03(0.18)$ & $1.18(0.43)$ \\
\hline $\begin{array}{l}\text { Madobi } \\
(n=51)\end{array}$ & 1.00 & 1.00 & 1.00 & $1.02(0.14)$ & 1.00 & 1.00 & $1.00(0.02)$ \\
\hline $\begin{array}{l}\text { Gezawa } \\
(n=51)\end{array}$ & $3.25(0.95)$ & $3.21(0.92)$ & $3.47(0.76)$ & $3.39(0.77)$ & $3.43(0.92)$ & $3.35(0.87)$ & $3.35(0.59)$ \\
\hline $\begin{array}{l}\text { Kumbutso } \\
(n=50)\end{array}$ & 1.00 & 1.00 & 1.00 & 1.00 & 1.00 & 1.00 & 1.00 \\
\hline $\begin{array}{l}\text { Rimin Gado } \\
\quad(n=50)\end{array}$ & $3.14(0.78)$ & $3.02(0.79)$ & $3.46(0.68)$ & $3.38(0.72)$ & $3.22(0.76)$ & $3.22(0.79)$ & $3.24(0.49)$ \\
\hline Total $(N=521)$ & $1.67(1.12)$ & $1.74(1.14)$ & $1.84(1.23)$ & $1.85(1.22)$ & $1.83(1.21)$ & $1.71(1.14)$ & $1.77(1.09)$ \\
\hline
\end{tabular}

Note: Values are challenge scales in assessing the challenge experienced based on a scale from 1 (no challenge encountered) to 5 (severe challenge, was impossible to access). Colours reflect $p$-values based on $t$-tests between the scale of each challenge and the dichotomous (yes/no) perception that the challenges were worsened by the COVID-19 pandemic. Values in green, blue and red indicate $p>0.10,0.05$ and 0.01 , respectively. Values in parentheses are standard deviations.

\subsection{COVID-19 Coping Strategies and the Socio-Economic Drivers}

We find that respondents developed up to seven strategies to cope with the COVID-19 situation, namely: producing less vegetables for selling, producing more vegetables than before the pandemic for own consumption, eating more own production rather than selling, storing more vegetables, processing more vegetables, finding new markets, and accepting a lower selling price. These coping strategies can be categorised into two groups of production-oriented strategies aimed at managing supplies and market-oriented strategies aimed at transforming the produce and finding alternative markets. Table 7 shows the shares of respondents using each strategy per LGA.

Table 7. Share of farm households using various coping strategies in vegetable production and marketing.

\begin{tabular}{|c|c|c|c|c|c|c|c|}
\hline \multirow{2}{*}{ LGA } & \multicolumn{3}{|c|}{ Production-Oriented Strategies } & \multicolumn{4}{|c|}{ Market-Oriented Strategies } \\
\hline & $\begin{array}{l}\text { Producing } \\
\text { Less Crops for } \\
\text { Selling (1/0) }\end{array}$ & $\begin{array}{l}\text { Producing } \\
\text { More of Own } \\
\text { Food (1/0) }\end{array}$ & $\begin{array}{c}\text { Eat More Own } \\
\text { Production } \\
(1 / 0)\end{array}$ & $\begin{array}{c}\text { Process More } \\
(1 / 0)\end{array}$ & $\begin{array}{l}\text { Store More } \\
\quad(\mathbf{1} / \mathbf{0})\end{array}$ & $\begin{array}{c}\text { Find New } \\
\text { Markets (1/0) }\end{array}$ & $\begin{array}{l}\text { Reduce the } \\
\text { Selling Price } \\
(1 / 0)\end{array}$ \\
\hline Kudan $(\mathrm{n}=59)$ & 0.00 & 0.00 & $0.32(0.47)$ & $0.02(0.13)$ & $0.12(0.33)$ & 0.00 & $0.17(0.38)$ \\
\hline Ikara $(\mathrm{n}=50)$ & 0.00 & 0.00 & $0.54(0.50)$ & $0.06(0.24)$ & $0.10(0.30)$ & $0.04(0.26)$ & $0.12(0.33)$ \\
\hline $\begin{array}{c}\text { Dawakin Kudu } \\
\quad(\mathrm{n}=80)\end{array}$ & $0.02(0.16)$ & $0.04(0.19)$ & $0.06(0.24)$ & $0.37(0.49)$ & $0.47(0.50)$ & $0.02(0.16)$ & $0.05(0.22)$ \\
\hline $\begin{array}{l}\text { Dawakin Tofa } \\
\quad(\mathrm{n}=72)\end{array}$ & $0.51(0.50)$ & $0.01(0.12)$ & $0.01(0.12)$ & 0.00 & 0.00 & $0.01(0.12)$ & 0.00 \\
\hline $\begin{array}{l}\text { Minjibir } \\
(\mathrm{n}=29)\end{array}$ & $0.72(0.45)$ & 0.00 & 0.00 & 0.00 & 0.00 & 0.00 & 0.00 \\
\hline $\begin{array}{l}\text { Garko } \\
(\mathrm{n}=29)\end{array}$ & 0.00 & 0.00 & 0.00 & $0.62(0.49)$ & $0.45(0.51)$ & 0.00 & 0.00 \\
\hline $\begin{array}{l}\text { Madobi } \\
(\mathrm{n}=51)\end{array}$ & $0.08(0.27)$ & $0.61(0.49)$ & $0.13(0.35)$ & $0.25(0.44)$ & $0.53(0.50)$ & 0.00 & 0.00 \\
\hline $\begin{array}{l}\text { Gezawa } \\
(\mathrm{n}=51)\end{array}$ & $0.06(0.24)$ & $0.06(0.24)$ & $0.47(0.50)$ & $0.08(0.27)$ & $0.14(0.35)$ & $0.11(0.33)$ & $0.14(0.35)$ \\
\hline $\begin{array}{l}\text { Kumbutso } \\
(\mathrm{n}=50)\end{array}$ & $0.02(0.14)$ & $0.68(0.47)$ & $0.58(0.50)$ & $0.12(0.33)$ & $0.10(0.30)$ & 0.00 & 0.00 \\
\hline $\begin{array}{l}\text { Rimin Gado } \\
(\mathrm{n}=50)\end{array}$ & 0.00 & $0.06(0.24)$ & $0.96(0.20)$ & $0.08(0.27)$ & $0.04(0.19)$ & 0.00 & $0.02(0.14)$ \\
\hline Total $(\mathrm{N}=521)$ & $0.13(0.34)$ & $0.14(0.35)$ & $0.31(0.46)$ & $0.15(0.36)$ & $0.20(0.40)$ & $0.02(0.14)$ & $0.05(0.22)$ \\
\hline
\end{tabular}


Results show that vegetables farmers tended to adopt more production-oriented coping strategies than market-oriented strategies. The reduction of the supply volume involves income losses for farmers that can be offset by improved nutritional status if vegetables produced at home are consumed to a greater extent. Market-oriented strategies in general might limit income losses but often require investments in storage and processing, access or development of new markets or even price reductions. These strategies come with some transaction costs that farmers might not be able to afford.

To better understand the respondents' choices, Table 8 presents the results of the multivariate probit regression model. The explanatory variables considered in the regression model drive differentially the choices of the different COVID-19 coping strategies.

Drivers of production-oriented coping strategies:

- $\quad$ Age: We observe that older farmers tend to reduce the supply volume by producing more of their own food $(p<0.01)$. This can be explained by the fact that older farmers have less physical capacity to make investments and tend to prefer falling back to subsistence production.

- Education: The level of education shows mixed-effects on the decisions to adopt production-oriented coping strategies that are aimed at reducing the supply volume. More educated farmers are less likely to opt for producing more of their own food $(p<0.10)$ and this helps them to control better what they eat. In the same way, these farmers are more likely to eat more of their own production $(p<0.10)$ given that they faced more difficulties to sell their vegetables and want to avoid income losses.

- Marital status: Married farmers are found to be more likely to adopt productionoriented strategies that reduce the supply volume by deciding to produce less crops for selling $(p<0.01)$. As hypothesised, for married farmers, it is critical to ensure that income flows from sales to meet non-food expenses and they have lower incentive if market prices or demand are reduced for some crops. This could also be the result of a strategy diverting the required amount required for producing of crops for selling to other activities with a more "guaranteed" demand as vegetable production may be perceived as risky considering the lower demand and high perishability in the context of the pandemic.

- Household size: Larger households were less likely to reduce their supply volume compared to smaller households $(p<0.01)$. Farmers with a higher number of household members were more likely to engage in coping strategies that are labour intensive and also allow them producing enough food for their households. Access and entitlement to natural capital significantly determined the decisions taken by smallholder African traditional vegetable farmers to cope with shocks [32].

- Household asset index: Wealthier households had mixed behaviours in terms of production-oriented coping strategies. Wealthier households were less likely to produce less crops for selling and more likely to produce more for own consumption.

- Credit access: Access to credit mostly drove production-oriented coping strategies that reduced vegetable supply. The estimated coefficients are significant on the decisions to produce less crops for selling $(p<0.01)$ and producing more of own food $(p<0.10)$. This indicates that farmers who have access to credit are likely to maintain their production, but switch from supplied markets to using more for their own consumption. This could help smooth the impact on food consumption.

- Private extension services: Private extension services have mixed-effects on the farmers' decisions towards production-strategies that reduce the supply volume. These services encourage farmers to produce more crops for selling $(p<0.01)$ and also to produce more of own food $(p<0.01)$.

- Perception of the effects of COVID-19: A stronger perception of COVID-19 seems to encourage farmers to produce more crops for selling. This could be because farmers also understand that more nutritious and healthy food that include vegetables are recommended. This also highlights the existence of a demand for vegetable that could encourage farmers to produce more, if well communicated. 
- Challenge in accessing farm inputs: Unexpectedly, farmers who faced more challenges in accessing farm inputs were less likely to adopt coping strategies such as producing less crops for selling $(p<0.01)$.

- Challenge in storage and sales: Farmers who faced more challenges in storage and sales were more likely to produce less crops for selling $(p<0.01)$. This way, they avoid post-harvest losses especially if they were not able to sell out all their production.

Drivers of market-oriented strategies coping strategies:

- Age: Compared to younger farmers, older farmers are also less likely to adopt marketoriented strategies such as more processing $(p<0.05)$ or finding new markets $(p<0.01)$. Like in the case of production-oriented strategies, it may be that older farmers have less capacity to make investments and tend to prefer falling back to subsistence production.

- Marital status: Married farmers had mixed-behaviours in relation with respect to market-oriented strategies. They tend to process less $(p<0.05)$ but explore new markets $(p<0.01)$. Consistent with the above explanation on production-oriented strategies, married farmers reduce their production but still explore new markets to sell their products.

- Household size: Despite the market challenges, larger households were less likely to invest in storing $(p<0.01)$.

- Production in the last 12 months: Farmers who declared that they produced vegetables within the 12 months preceding the survey were more likely to adopt market-oriented coping strategies such as processing $(p<0.05)$ and reducing the selling price $(p<0.05)$. These farmers are typically those who were able to sustain their production (i.e., start new cultivation cycles) to some extent despite the pandemic and who needed to sell their products.

- Government extension services: Farmers who benefited from government extension services were more likely to adopt market-oriented coping strategies and more precisely the reduction of selling price $(p<0.05)$.

- Challenge in accessing farm inputs: Farmers who faced more challenges in accessing farm inputs were less likely to look for new markets $(p<0.05)$. As they produce less for selling, they also limit their investments in alternative markets.

- Challenge in storage and sales: Farmers who faced more challenges in storage and sales were also more likely to adopt coping strategies such as processing $(p<0.05)$ and finding new markets $(p<0.05)$. They seem to be aware of the market demand and consider storage as a key constraint to solve.

In their study on household well-being and coping strategies in Africa during COVID-19, Koos et al. [36] highlighted the lack of evidence on the impact of the pandemic on food insecurity among poor households, suggesting that these households first reduce consumption of other goods and services and turn to crisis level coping strategies to maintain food consumption, even if this has long-term welfare consequences. Our results suggest that farmers have specific coping strategies as well. 
Table 8. Results of the multivariate probit model.

\begin{tabular}{|c|c|c|c|c|c|c|c|}
\hline \multirow[b]{2}{*}{ Explanatory Variables } & \multicolumn{3}{|c|}{ Production-Oriented Strategies } & \multicolumn{4}{|c|}{ Market-Oriented Strategies } \\
\hline & $\begin{array}{l}\text { Producing Less Crops } \\
\text { for Selling (1/0) }\end{array}$ & $\begin{array}{l}\text { Producing More for Own } \\
\text { Consumption (1/0) }\end{array}$ & $\begin{array}{l}\text { Eat More Own } \\
\text { Production (1/0) }\end{array}$ & Process More (1/0) & Store More (1/0) & $\begin{array}{l}\text { Find New } \\
\text { Markets (1/0) }\end{array}$ & $\begin{array}{c}\text { Reduce the Selling } \\
\text { Price (1/0) }\end{array}$ \\
\hline Age (years) & $-0.01(0.01)$ & $0.02 * * *(0.00)$ & $4 \times 10^{-3}(0.01)$ & $-0.01^{* *}(0.00)$ & $-4 \times 10^{-3}(0.01)$ & $-0.04^{* * *}(0.01)$ & $1 \times 10^{-3}(0.01)$ \\
\hline $\begin{array}{l}\text { HH head currently } \\
\text { married }(1 / 0)\end{array}$ & $0.44^{* * *}(0.09)$ & $-0.51(0.94)$ & $-0.19(0.29)$ & $-0.88^{* *}(0.44)$ & $-0.01(0.17)$ & $0.47^{* * *}(0.18)$ & $-0.19(0.22)$ \\
\hline HH size (\# people) & $-0.04^{* * *}(0.02)$ & $\begin{array}{l}0.01(0.09) \\
1.53^{* *}(0.64)\end{array}$ & $\begin{array}{l}0.03(0.03) \\
0.36(0.71)\end{array}$ & $-0.00(0.03)$ & $\begin{array}{l}-0.07 * * *(0.03) \\
-0.89(067)\end{array}$ & $\begin{array}{l}-0.00(0.06) \\
-0.73(181)\end{array}$ & $\begin{array}{l}0.06(0.03) \\
-0.63(0.47)\end{array}$ \\
\hline $\begin{array}{l}\mathrm{HH} \text { assets index } \\
\text { Production the last } 12\end{array}$ & $-1.24^{* * * *}(0.43)$ & & & & & & $\begin{array}{l}-0.63(0.47) \\
0.55 * *(0.27)\end{array}$ \\
\hline months $(1 / 0)$ & $0.15(0.29)$ & $0.12(0.29)$ & $0.18(0.15)$ & $0.71^{* *}(0.34)$ & $0.09(0.21)$ & $-0.73(0.87)$ & $0.55^{* *}(0.27)$ \\
\hline Credit access $(1 / 0)$ & $-0.89^{* * *}(0.25)$ & $4.95 *(2.61)$ & $-0.01(0.58)$ & $-0.02(0.23)$ & $-0.03(0.19)$ & $4.17(23.76)$ & $-2 \times 10^{-11}(5.80)$ \\
\hline $\begin{array}{l}\text { Government extension } \\
\text { services }(1 / 0)\end{array}$ & $-0.53(0.39)$ & $0.39(0.43)$ & $-0.01(0.37)$ & $-0.46(0.28)$ & $0.54(0.29)$ & $0.64(0.71)$ & $0.65^{* *}(0.32)$ \\
\hline $\begin{array}{l}\text { Private extension } \\
\text { services }(1 / 0)\end{array}$ & $-0.61^{* * *}(0.25)$ & $0.78^{* * *}(0.14)$ & $0.53(0.40)$ & $-0.33(0.41)$ & $0.29(0.21)$ & $-0.11(0.47)$ & $0.05(0.40)$ \\
\hline $\begin{array}{l}\text { Effects of COVID-19 } \\
\text { (mean perception score) }\end{array}$ & $-0.41^{* * *}(0.13)$ & $-0.18(0.36)$ & $0.11(0.18)$ & $-1 \times 10^{-3}(0.23)$ & $0.28(0.17)$ & $-0.014(0.31)$ & $-0.19(0.22)$ \\
\hline $\begin{array}{l}\text { Challenge in accessing } \\
\text { inputs (mean } \\
\text { perception score) }\end{array}$ & $-0.44^{* * *}(0.16)$ & $0.25(0.45)$ & $-0.14(0.15)$ & $-0.40(0.27)$ & $-0.19(0.26)$ & $-0.69 * *(0.29)$ & $-0.10(0.24)$ \\
\hline
\end{tabular}

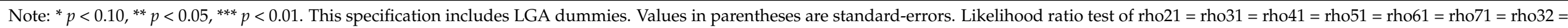
rho42 $=$ rho52 $=$ rho62 $=$ rho72 $=$ rho43 $=$ rho53 $=$ rho63 $=$ rho73 $=$ rho54 $=$ rho64 $=$ rho74 $=$ rho65 $=$ rho75 $=$ rho76 $=0$ : chi2 $(21)=749.25$ and Prob $>$ chi2 $=0.0000$. 
The observed coping strategies and related drivers are consistent with farmers' responses to other challenges. Yet, the literature documents a broader range of solutions. Farmers develop various coping strategies to respond to economic disturbances (e.g., price volatility, distorted trading conditions, lack of financial resources, and restrictive governmental regulations), social disturbances (e.g., limited succession prospects, depopulation of rural areas and changing consumer habits), and environmental disturbances (e.g., adverse weather conditions, threats to animal health and unsustainable farming practices) [37]. In addition to these disturbances, coping strategies can also help respond to demographic and social changes such as ageing and worsening health conditions. The strategies include seeking public support, operating in the informal sector, occupational diversification (engaging in other on- and off-farm work), reprofiling (downscaling and reducing farming activities to make them more compatible with new conditions), switching to less energyconsuming endeavours/occupations, adoption of cost-saving technologies, prioritisation of activities, outsourcing of certain activities, personal upskilling, informal cooperation among farmers and advice-seeking [37]. Other strategies reported in the literature are: engaging in on-farm processing and off-farm employment, renting out or selling part of the land and rescheduling on-farm tasks, cautious and conservative investment decisions, introduction of niche crops, and diversification of market opportunities. All the strategies we identified fall under the reprofiling strategies [37-40]. Depending on the progress of the COVID-19 pandemic, the observed coping strategies might have to evolve into adaptation strategies if the crisis were to last much longer.

It is important to note that the data underlying our study are based on the perceptions of respondents, which need to be interpreted as such.

\section{Conclusions}

COVID-19 forms a major challenge to farmers globally and particularly to those producing perishable produce such as vegetables. The adoption of various coping strategies is therefore an important aspect of household resilience. Our study identified various coping strategies developed by vegetable farmers in selected locations of north-western Nigeria and identified factors associated with them. The COVID-19 measures have both direct and indirect effects on the households perceived by the farmers as moderately affecting them (mean score of 3.1 out of 5). Farmers perceived challenges as slightly more acute in storing and selling vegetables (average challenge score about 1.8 out of 5) than in accessing farm inputs (average challenge score about 1.5 out of 5). They adopted several coping strategies that can be grouped as production- and market-oriented strategies. Socio-economic characteristics such as age, education level, marital status, household size, assets index, vegetable production during the last 12 months, access to credit, access to government or private extension services, perception of the effects of COVID-19, perception of challenge in accessing inputs, and perception of challenge in storage and selling affect differentially the decision of smallholder farmers to adopt coping strategies.

These results highlight potential actions that could be taken to encourage production but also access to the market. For instance, policy makers may want to promote more market-oriented strategies through government extension services. The COVID-19 pandemic could also be an opportunity to invest more in innovations enabling vegetable storage and processing. Other interventions might include: strengthening existing inputs subsidy programs to ensure adequate supply of affordable inputs to most farmers and creating enabling environments for farmers and consumers to collaborate and build trusts to support each other. These potential interventions are avenues that future research can explore and test using rigorous methodologies.

Author Contributions: Research design, P.S. and M.B.; data collection, I.O.; data analysis, R.N.Y., C.M.K.A. and P.S.; writing-original draft preparation, R.N.Y., C.M.K.A. and P.S.; writing-review and editing, P.S., I.O., M.B., V.A.-S., R.N.Y. and C.M.K.A.; supervision, P.S. All authors have read and agreed to the published version of the manuscript. 
Funding: This work was funded by the UK Government's Foreign, Commonwealth \& Development Office (FCDO) and other long-term strategic donors to the World Vegetable Center: Taiwan, United States Agency for International Development (USAID), Australian Centre for International Agricultural Research (ACIAR), Germany, Thailand, Philippines, Korea, and Japan. Funding sources had no other involvement in the study.

Institutional Review Board Statement: The study was conducted according to the guidelines of the Declaration of Helsinki. The study was exempted from ethical review by the Institutional Biosafety and Research Ethics Committee (IBREC) of the World Vegetable Center (Exempt 2020-001) on 4 February 2020.

Informed Consent Statement: Informed consent was obtained from all subjects involved in the study.

Data Availability Statement: Data are available upon request.

Acknowledgments: We acknowledge the support received from East-West Seed Knowledge Transfer in selecting farmers for this study. We thank the anonymous reviewers for their helpful comments and suggestions.

Conflicts of Interest: The authors declare no conflict of interest.

\section{References}

1. Ali, Z.; Green, R.; Zougmoré, R.B.; Mkuhlani, S.; Palazzo, A.; Prentice, A.M.; Haines, A.; Dangour, A.D.; Scheelbeek, P.F.D. Long-term impact of West African food system responses to COVID-19. Nat. Food 2020, 1, 768-770. [CrossRef]

2. Bisson, L.; Hambleton, T. COVID-19 Impact on West African Value Chains Countries. In CRU_Clingendael Policy Brief. Available online: https://www.clingendael.org/sites/default/files/2020-06/Policy_Brief_COVID-19_Impact_on_West_African_Value_ Chains_June_2020.pdf (accessed on 16 August 2021).

3. Mahmud, M.; Riley, E. Household response to an extreme shock: Evidence on the immediate impact of the Covid-19 lockdown on economic outcomes and well-being in rural Uganda. World Dev. 2021, 140, 21. [CrossRef]

4. Mhlanga, D.; Ndhlovu, E. Socio-Economic Implications of the COVID-19 Pandemic for Smallholder Livelihoods in Zimbabwe. Sahar. J. 2020, 1, 174-199.

5. OECD. Evaluation of the Impact of the Coronavirus (COVID-19) on Fruit and Vegetables Trade, pp. 1-14. 2020. Available online: https:/ / www.oecd.org/agriculture/fruit-vegetables/oecd-covid-19-impact-on-fruit-and-vegetables-trade.pdf (accessed on 1 September 2021).

6. Ozili, P. COVID-19 in Africa: Socio-Economic Impact, Policy Response and Opportunities. Int. J. Sociol. Soc. Policy 2020, 25. Available online: https://www.emerald.com/insight/content/doi/10.1108/IJSSP-05-2020-0171/full/html (accessed on 1 September 2021).

7. FAO. Promotion of Fruit and Vegetables for Health: Report of the Pacific Regional Workshop. Available online: http://www.fao. org/3/a-i4935e.pdf (accessed on 6 August 2021).

8. Hamulczuk, M.; Skrzypczyk, M. COVID-19, spatial market integration and producer prices: A case study of eu agri-food markets. Stud. Agric. Econ. 2021, 123, 53-61. [CrossRef]

9. Aman, F.; Masood, S. How Nutrition can help to fight against COVID-19 Pandemic. Pak. J. Med. Sci. 2020, 36, 121-123. [CrossRef]

10. De Faria Coelho-Ravagnani, C.; Corgosinho, F.C.; Sanches, F.L.F.Z.; Prado, C.M.M.; Laviano, A.; Mota, J.F. Dietary recommendations during the COVID-19 pandemic. Nutr. Rev. 2021, 79, 382-393. [CrossRef]

11. Dessalegn, B. Transitory coping strategies of food-insecure smallholder farmer households: The case of Ilu Gelan District, West Shoa Zone, Oromia Reginal State, Ethiopia. Agric. Food Secur. 2018, 7, 70. [CrossRef]

12. FAO. Fruit and vegetables-Your dietary essentials. In The International Year of Fruits and Vegetables, 2021, Background Paper; FAO: Rome, Italy, 2020; p. 36. [CrossRef]

13. Asante, L.A.; Mills, R.O. Exploring the Socio-Economic Impact of COVID-19 Pandemic in Marketplaces in Urban Ghana. Afr. Spectr. 2020, 55, 170-181. [CrossRef]

14. FAO. FAO's Response to COVID-19: Building to Transform, Council Hundred and Sixty-Sixth Session (cl 166/5), 14p, no. Hundred and Sixty-Sixth Session (166/5), p. 14. 2021. Available online: http://www.fao.org/3/ne895en/ne895en.pdf (accessed on 1 September 2021).

15. Lucas, B. Impacts of Covid-19 on Inclusive Economic Growth in Middle-Income Countries, K4D Helpdesk Report 811; Institute of Development Studies: Brighton, UK, 2020; Volume 811, p. 32.

16. World Bank Group. Commodity Markets Outlook. Implications of COVID-19 for Commodities, Worldbank, no. April, pp. 1-100. 2020. Available online: https:/ / openknowledge.worldbank.org/bitstream/handle/10986/33624/CMO-April-2020.pdf? sequence $=9$ \&isAllowed $=y$ (accessed on 11 August 2021).

17. Tsiboe, F.; Asravor, J.; Osei, E. Vegetable production technical efficiency and technology gaps in Ghana. Afr. J. Agric. Resour. Econ. 2019, 14, 255-278. 
18. Gu, H.-Y.; Wang, C.-W. Impacts of the COVID-19 pandemic on vegetable production and countermeasures from an agricultural insurance perspective. J. Integr. Agric. 2020, 19, 2866-2876. [CrossRef]

19. Abdul, I.M. COVID-19, Lockdown And Transitory Food Insecurity In Nigeria. Food Agribus. Manag. 2020, 1, 31-35. [CrossRef]

20. Aromolaran, A.B.; Muyanga, M. Impact of COVID-19 on Food Systems and Rural Livelihoods in Nigeria. Round 2. In Agricultural Policy Research in Africa (APRA) COVID-19 Country Report; Future Agricultures Consortium (): Brighton, UK, 2020; Volume 7, pp. 2-3. [CrossRef]

21. Harris, J. Diets in a Time of Coronavirus: Don't Let Vegetables Fall off the Plate. IFPRI Blog Post, pp. 1-5. 2020. Available online: https:/ / www.ifpri.org/blog/diets-time-coronavirus-dont-let-vegetables-fall-plate (accessed on 6 August 2021).

22. Harris, J.; Depenbusch, L.; Pal, A.A.; Nair, R.M.; Ramasamy, S. Food system disruption: Initial livelihood and dietary effects of COVID-19 on vegetable producers in India. Food Secur. 2020, 12, 841-851. [CrossRef]

23. Ridley, W.; Devadoss, S. The Effects of COVID-19 on Fruit and Vegetable Production. Appl. Econ. Perspect. Policy 2021, 43, 329-340. [CrossRef] [PubMed]

24. Tamru, S.; Hirvonen, K.; Minten, B. Impacts of the COVID-19 Crisis on Vegetable Value Chains in Ethiopia; IFPRI: International Food Policy Research Institute: Washington, DC, USA, 2020; pp. 81-83. Available online: https:/ /www.ifpri.org/blog/impacts-covid19-crisis-vegetable-value-chains-ethiopia (accessed on 14 March 2021).

25. Varrella, S. Nigeria: Agricultural Activities, by Type and Area. 2020. Available online: https://www.statista.com/statistics/1119 593/households-participating-in-agricultural-activities-in-nigeria-by-type-and-area/ (accessed on 17 May 2021).

26. Mukaila, R.; Obetta, A.E.; Awoyelu, F.E.; Chiemela, C.J.; Ugwu, A.O. Marketing Analysis of Vegetables: The Case of Carrot and Cucumber Marketing in Enugu State, Nigeria. Turk. J. Agric.-Food Sci. Technol. 2021, 9, 346-351. [CrossRef]

27. World Population Prospects. The 2019 Revision: Nigeria Population. 2021. Available online: https://www.worldometers.info/ world-population/nigeria-population/ (accessed on 13 May 2021).

28. ILO. Rapid Situational Analysis of the Employment-Climate- Environment Nexus Nigeria: Identifying Just Transition Policies; ILO: Geneva, Switzerland, 2020; p. 20. Available online: https://www.ilo.org/global/topics/green-jobs/publications/situationalanalysis/WCMS_757097/lang--en/index.htm (accessed on 1 September 2021).

29. Greene, W.H. Discrete Choice Modeling. In The Handbook of Econometrics: Vol. 2, Applied Econometrics; Forthcomin, Volume 2, no. January 2007; Mills, T., Patterson, K., Eds.; Palgrave: London, UK, 2000; pp. 7-78. Available online: https://www.researchgate. net/publication/24133061 (accessed on 20 August 2021).

30. Cappellari, L.; Jenkins, S.P. Multivariate probit regression using simulated maximum likelihood. Stata J. 2003, 3, 278-294. [CrossRef]

31. Sharma, M. Coping: Strategies. 2003. Available online: https://www.researchgate.net/publication/274193314_Coping_Strategies (accessed on 12 May 2021).

32. Ngenoh, E.; Kebede, S.W.; Bett, H.K.; Bokelmann, W. Coping with Shocks and Determinants among Indigenous Vegetable Smallholder Farmers in Kenya. Agric. Sci. 2018, 9, 804-823. [CrossRef]

33. Lapatinas, A. The effect of COVID-19 Confinement Policies on Community Mobility Trends in the EU; Publications Office of the European Union: Luxembourg, 2020; p. 5. Available online: https://publications.jrc.ec.europa.eu/repository/handle/JRC120972 (accessed on 1 September 2021).

34. PWC. Responding To the Impact of COVID-19 on Food Security and Agriculture in Nigeria. 2020. Available online: www.pwc. $\mathrm{com} / \mathrm{ng} /$ covid-19 (accessed on 19 June 2021).

35. Ilesanmi, F.F.I.; Ilesanmi, O.S.; Afolabib, A. The effects of the COVID-19 pandemic on food losses in the agricultural value chains in Africa: The Nigerian case study. Public Heal. Pract. 2020, 2, 3. [CrossRef]

36. Koos, C.; Hangoma, P.; Maestad, O. Household Wellbeing and Coping Strategies in Africa during COVID-19: Findings from High Frequency Phone Surveys, Chr. Michelsen Institute (cmi) Report, No. 4, p. 32. 2020. Available online: www.cmi.no/ publications /7391-household-wellbeing-and-coping-strategies-in-africa-during-covid-19-findings-from-high-frequency (accessed on 1 September 2021).

37. Czekaj, M.; Adamsone-Fiskovica, A.; Tyran, E.; Kilis, E. Small farms' resilience strategies to face economic, social, and environmental disturbances in selected regions in Poland and Latvia. Glob. Food Sec. 2020, 26, 8. [CrossRef]

38. Darnhofer, I.; Fairweather, J.; Moller, H. Assessing a farm's sustainability: Insights from resilience thinking. Int. J. Agric. Sustain. 2010, 8, 186-198. [CrossRef]

39. Van Vliet, J.A.; Schut, A.G.T.; Reidsma, P.; Descheemaeker, K.; Slingerland, M.; Van de Ven, G.W.J.; Giller, K.E. De-mystifying family farming: Features, diversity and trends across the globe. Glob. Food Sec. 2015, 5, 11-18. [CrossRef]

40. Daugstad, K. Resilience in mountain farming in Norway. Sustainability 2019, 11, 3476. [CrossRef] 